\title{
アルゴンガスクラスターを用いた二次イオン質量分析法による 有機物の表面敏感分析*
}

盛谷 浩右 $* 1 \cdot$ 持地 広造*1. 乾 徳夫*1

豊田 紀章*2 $\cdot$ 山田 公*2

\section{Surface Sensitive Analysis of Organic Compound using Size-selected Ar Gas Cluster SIMS}

Kousuke MORITANI*1, Kozo MOCHIJI*1, Norio INUI*1, Noriaki TOYODA*2 and Isao YAMADA*2

*1Department of Mechanical and System Engineering, Graduate School of Engineering, University of Hyogo, 2167 Shosha, Himeji-shi, Hyogo 671-2201, Japan

*2Incubation Center, Graduate School of Engineering, University of Hyogo, 2167 Shosha, Himeji-shi, Hyogo, 671-2201, Japan

(Received January 31, 2014, Accepted March 18, 2014)

\begin{abstract}
A size-selected Ar gas cluster ion beam (GCIB) was applied to secondary ion mass spectrometry (SIMS) of a polystyrene (PS) thin film, a 1,4-didodecylbenzene (DDB) thin film, and an ITO glass sample. Additionally, the samples were analyzed by SIMS using an atomic $\mathrm{Ar}^{+}$ion projectile and X-ray photoelectron spectroscopy (XPS). All three samples were contaminated by poly (dimethylsiloxane) (PDMS) on the surface. Compared to the $\mathrm{Ar}^{+}$SIMS spectra, the fragments in the PS and DDB SIMS spectra for $\mathrm{Ar}_{1550}{ }^{+}$, including siloxane, were enhanced more than $\sim 100$-fold, while the hydrocarbon fragments were enhanced 10-20-fold. XPS spectra during beam irradiation indicate that Ar-GCIB sputters contaminants on the surface more effectively than the atomic $\mathrm{Ar}^{+}$ion beam. These results indicate that a large gas cluster projectile can sputter a much shallower volume of organic material than small projectiles, resulting in an extremely surface-sensitive analysis of organic thin films. The shallow volume sputtering by GCIB is responsible for the preferential enhancement of the surface contaminants.
\end{abstract}

\section{1. はじめに}

近年，有機デバイスやバイオマテリアル等，有機系先端材 料の発達に伴い，有機高分子材料の表面第一層を化学分析す る必要性が高まっている，例えば，有機デバイスに用いられ る有機半導体表面の分子や污染物の特定は，品質保証やプロ セス制御のために重要な情報である. また，高分子系先端材 料の開発では, しばしば表面第一層に化学処理を施すことで 材料の物性や化学的特性の向上が図られてきた。 そのため, 材料表面に存在する分子の種類や構造を特定することは, 新 材料の開発にとって重要である.

表面の化学分析技術のひとつに二次イオン質量分析法 (SIMS) がある. SIMS はイオンビームを試料表面に照射 し, スパッタ現象により放出される二次イオンを質量分析し て，表面に存在する元素及び化合物を同定する表面分析法で ある. SIMS は高感度な測定が可能であり，また分子の化学 構造に関する情報が直接的に得られるため, 有機高分子試料 表面の化学構造を同定することも可能である. しかし, 旧来 型のSIMS では，一次イオンの照射によって試料表面の分 子が破壞されるため, 得られる情報は制限されていた。 また 高エネルギーの一次イオンの照射によるノックオンやミキシ ングが表面層に擾乱を引き起こすため, 特に有機物試料の分 析では表面・界面部位の詳細な分析は困難であった。

* 平成25年11月27日 第54回真空に関する連合講演会で発表

*1 兵庫県立大学大学院工学研究科機械系工学専攻 (厂671-2201 兵庫県姫路市書写2167)

*2 兵庫県立大学大学院工学研究科インキュベーションセンター （干671-2201 兵庫県姫路市書写2167）
このような問題を解決するために, 近年 SIMS の一次イ オンとしてガスクラスターイオンビーム（GCIB）を利用す ることが検討されてきた ${ }^{1)}$. ガスクラスターイオンとは, 数 百から数千の気体分子が分子間力により凝集した巨大クラス ターをイオン化したものである. 通常, 数百 $\mathrm{eV}$ 数 $\mathrm{keV}$ の 運動エネルギーを持つイオンを固体表面に入射すると，イオ ンは自身の運動エネルギーを失いある深さで停止するまで固 体内原子との衝突を繰り返し, 結晶構造や有機分子の分子構 造を破壊しながら固体内に進入する。しかし，クラスターは 固体の結合に比べて非常に小さな力で凝集しているため, 固 体表面に衝突すると同時に分解してしまう。このとき，クラ スターを構成する原子 1 個当りの平均運動エネルギーは, クラスターの運動エネルギーをクラスター構成原子数（クラ スターサイズ）で割った值となるため，GCIB では 1 原子当 り数 $\mathrm{eV}$ 程度となる。 GCIB 照射ではこのような低エネル ギーの粒子が多体衝突するため, 旧来の一次イオンとは異な り，試料の分解を抑制したスパッタ2,3) や有機高分子材料の 高分解能深さ分析 ${ }^{4,5)}$ が可能となる. また，この数 $\mathrm{eV}$ は超熱 領域ではあるが，無機材料のスパッタ閾值よりは十分に低い エネルギーである ${ }^{6)}$. そのため基板表面の深さ方向への損傷 を回避し，最表面の吸着物だけをスパッタできる可能性があ る。実際に我々は，Ar-GCIBによるグラファイト表面に吸 着した DNA 分子のスパッタ現象について調べ，Arの 1 原 子当たり運動エネルギーを調節することで基板表面への損傷 を抑制して表面の DNA 分子のみをスパッタできることを示 してきた7)

これまでに，我々はクラスターサイズが数百から数千の巨 大なガスクラスターイオンのサイズを選別し，1原子当たり 


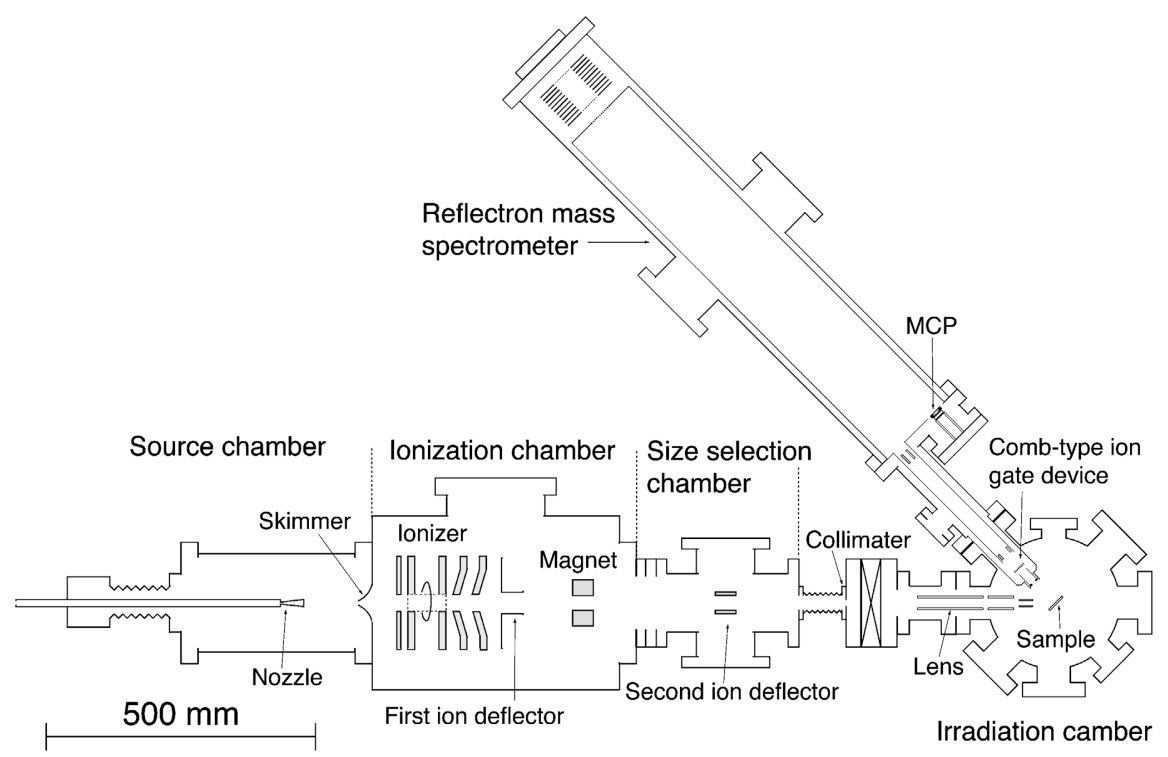

Fig. 1 Schematic top view of the size-selected TOF-SIMS machine.

のエネルギーを精密に調節できる GCIB を一次イオンとす る TOF-SIMS を開発してきた ${ }^{8)}$.そして，この手法をタン パク質に応用しスパッタ時の分子の解離を抑えることで，分 子量 $25 \mathrm{kDa}$ の分子イオンを検出した ${ }^{9)}$. さらに，1原子当 りのエネルギーを精密に調節することで，分子の化学結合の 切断を制御できること ${ }^{10,11)}$ や，表面の極浅い領域に存在する

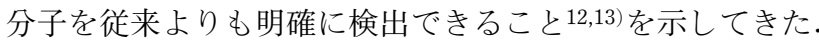

本研究では，本装置をポリスチレン（polystyrene; PS） 薄膜試料，ドデシルベンゼン (1,4-didodecylbenzene; DDB) 薄膜試料，インジウムースズ酸化膜（ITO） ガラス基板試料 に適用し，Ar-GCIB と $\mathrm{Ar}^{+}$を照射した際の SIMS スペクト ルを比較した．Ar-GCIB を照射した際のSIMS スペクトル では $\mathrm{Ar}^{+}$を照射した際と比較し，表面に污染物として存在 するポリジメチルシロキサン（poly (dimethylsiloxane）; PDMS）を数十から数百倍敏感に検出した。 また, Ar$\mathrm{GCIB}$ 抢よび $\mathrm{Ar}^{+}$イオンビームを照射しながら X 線光電子 分光 (XPS) 分析を行い, $\mathrm{Ar}-\mathrm{GCIB} か ゙ \mathrm{Ar}^{+}$よりも表面の活 染物質層を効率的にスパッタすることを示した。これらの結 果は，GCIB をSIMSの一次イオンとすることで，有機物試 料表面の極浅い領域のみを高感度で検出できることを示して いる.

\section{2. 実験方法}

\section{1 実験装置}

SIMS 分析とXPS 分析はそれぞれ異なる装置を用いた.

Fig. 1 に，本研究のSIMS 分析に用いたサイズ選別型ガス クラスターSIMS 装置 ${ }^{14,15)}$ の概要を示す。本装置のビーム ラインはクラスター生成部，イオン化部，サイズ選別部，照 射部とリフレクトロン型質量分析器から構成されている。 ク ラスター生成部では，オリフィス径 $0.1 \mathrm{~mm}$ ，拡散部長 60 $\mathrm{mm}$ のコニカルノズルから真空中にガスをジェット噴射し断 熱膨張させクラスタービームを生成する．生成した中性クラ スターは開孔径 $0.5 \mathrm{~mm}$ のスキマーにより中心部分を切り出

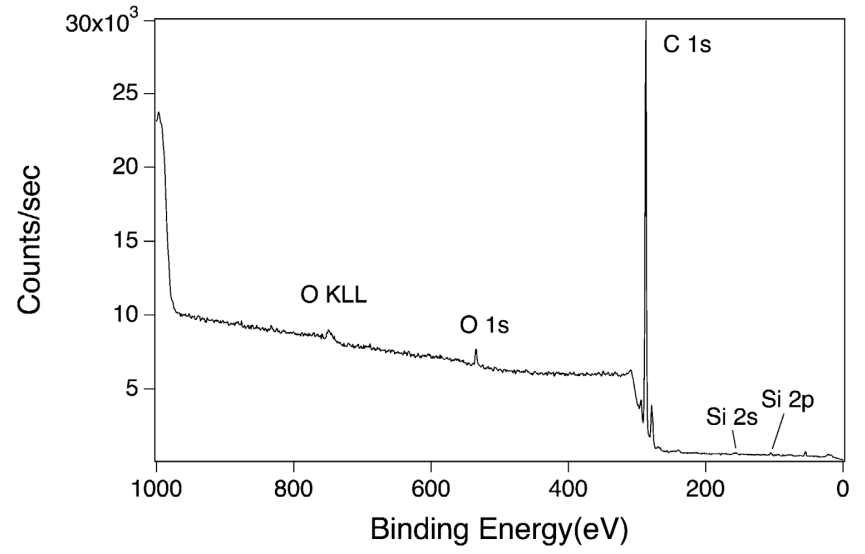

Fig. 2 XPS survey scan of PS thin film sample.

され，イオン化部に導入される.

イオン化部では, フィラメントから放出される熱電子の電 子衝撃により中性クラスターがイオン化される. 生成したク ラスターイオンはフィラメントの後段に設置された加速電極 によって試料方向に加速され，第一偏向電極によってパルス 化される.ビーム照射条件下での真空度はイオン化室, サイ ズ選別室，照射室がそれぞれ $4 \times 10^{-4}, 4 \times 10^{-4}, 5 \times 10^{-5}$ $\mathrm{Pa}$ であり, クラスターイオンビーム輸送中に残留ガスとの 衝突を防ぐのに十分な真空度である ${ }^{16)}$.

サイズ選別部において，第一，第二偏向電極間の飛行時間 によりクラスターサイズが選別され，照射部の試料に照射さ れる. 照射部の到達真空度は $7 \times 10^{-6} \mathrm{~Pa}$ である. 本研究で は，加速エネルギー $5 \mathrm{kV}$ または $10 \mathrm{kV}$ ，クラスターサイズ 1550 atoms/cluster で実験を行った。一次イオンの質量分解 能 $(m / \Delta m)$ は半值幅で5.2であった.

放出された二次イオンは， $-2 \mathrm{kV}$ の電圧によってリフレ クトロン型質量分析器に引き込まれた後, 櫛形ゲートデバイ ス (Comb-type ion gate device) ${ }^{17)}$ により $200 \mathrm{~ns}$ の幅でパル ス化され，それをスタート信号として飛行時間法（TOF） 


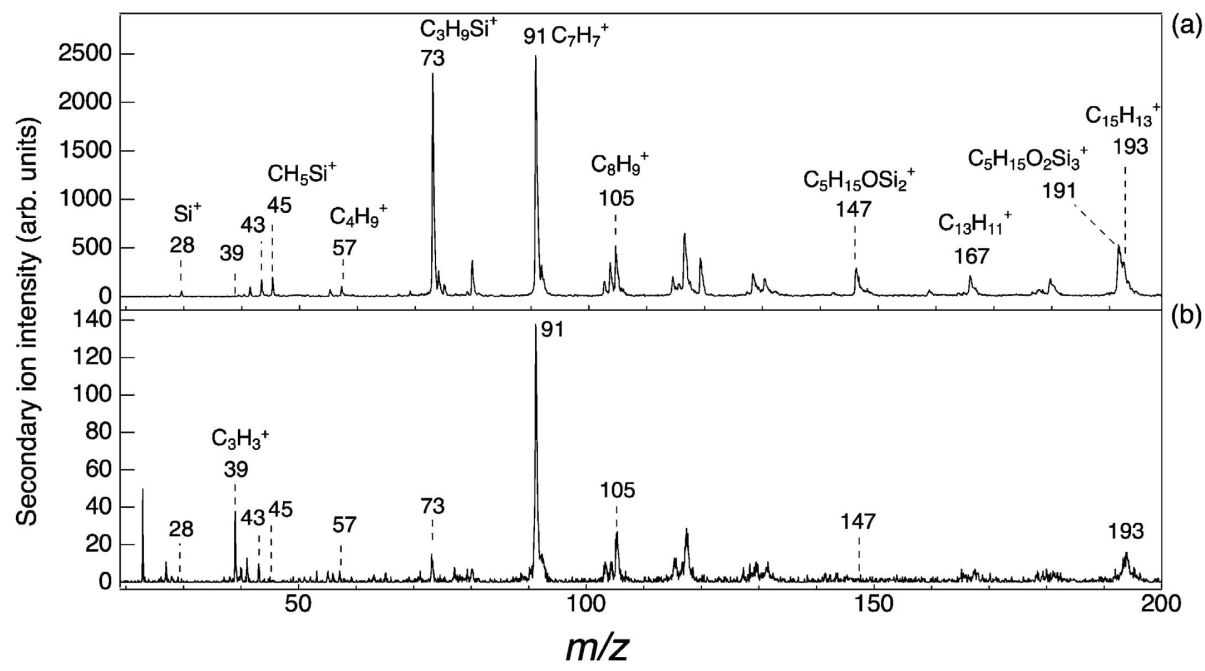

Fig. 3 Secondary ion mass spectra of PS thin film sample for (a) $\mathrm{Ar}_{1550}{ }^{+}$and (b) $\mathrm{Ar}^{+}$SIMS at an acceleration voltage of $10 \mathrm{kV}$. Data are taken from Ref. 13).

により質量分離される．二次イオンはマイクロチャンネルプ レート (Micro Channel Plate: MCP) によって検出し， MCP からの出力信号はマルチチャンネルスケーラ（Multi Channel Scalar: MCS) によるパルスカウントにより計測し た。二次イオンの質量較正は $\mathrm{Ar}_{2}^{+}(m / z 79.9)$ と $\mathrm{Ar}_{3}^{+}$ $(m / z 119.8)$ で行った.

XPS 分析は, XPS 装置 (JPS-9010MX, JEOL) に GCIB 導入部, 照射部を取り付けin situで行った。分析チャン バーの真空度は $2 \times 10^{-8} \mathrm{~Pa}$ であった．Ar-GCIBのクラス ターサイズ分布は TOF 法で決定した。本装置でのクラス ターサイズ分布のピーク値は 1500 atoms/cluster, $m / \Delta m$ は 半值幅で 3 であった.

\section{2 試料}

PS 試料 (和光純薬工業株式会社, 平均重合度約 2000) は, トルエンに濃度 $0.3 \%$ の重量比 $(\mathrm{w} / \mathrm{w})$ で溶解し, スピンコー 卜法により $\mathrm{Si}$ 基板上に塗布した。 DDB 試料 $\left(\mathrm{C}_{30} \mathrm{H}_{54}\right.$, $\mathrm{Mw}$ : 414.762, ALDRICH 社製) は，シクロヘキサン $(\mathrm{Mw}$ : 84.162, Wako 社製) で $1 \mathrm{~g} / l$ に希釈し調製した溶液を $\mathrm{Si}$ 基 板上に $20 \mu l$ 滴下した後, 大気中室温下で乾燥させた。PS および DDB 膜厚を触針式膜厚測定器で測定したところ, 平 均膜厚はそれぞれ $300 \pm 100 \mathrm{~nm} ， 30 \pm 10 \mathrm{~nm}$ であった。

ITO ガラス試料は ITO コートガラス（和光純薬工業株式 会社, LT-G002, ITO 膜厚 $310 \sim 370 \mathrm{~nm}$, 凹凸指数 Ra : 6 $\mathrm{nm}$ 以下）を用いたＩTO ガラスはアセトン及びメタノール でそれぞれ 5 分間超音波洗浄し, 乾燥窒素ガスを吹き付け て乾燥させた。

\section{3. 結果と考察}

\section{1 有機高分子薄膜の分析}

Fig. 2 にPS 薄膜試料の XPS 分析結果を示す. 光電子ス ペクトルには C 1s ピークの他に, PS の構成元素ではない Si 2s, Si 2p, O 1s, O KLL オージェのピークが検出された. これらのピークは DDB 薄膜試料でも同様に検出された. PS および DDB の膜厚は数十 $\mathrm{nm}$ 以上あるため,これらは $\mathrm{Si}$

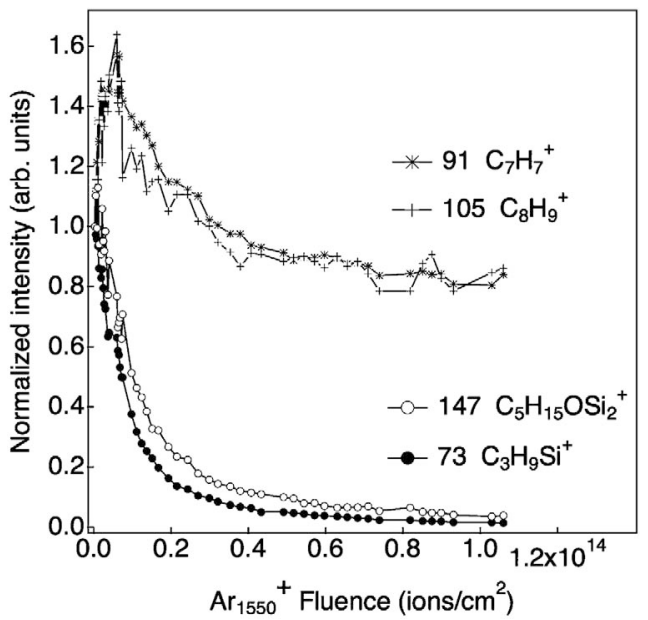

Fig. 4 Relative intensity of major secondary ion peaks in SIMS spectra of PS thin film sample as a function of primary ion fluence of $\mathrm{Ar}_{1550}{ }^{+}$at an acceleration voltage of $10 \mathrm{kV}$. Data are taken from Ref. 13).

基板ではなく試料に混在した污染物の存在を示している.

Fig. 3 に, PS 薄膜に $10 \mathrm{kV}$ の $\mathrm{Ar}_{1550}{ }^{+}$を照射した際の SIMS スペクトル (a) と, $\mathrm{Ar}^{+}$を照射した際の SIMS スペク トル (b)を示す．二次イオンカウントは一次イオン電流によ り規格化した．PS の特徵的なフラグメントイオンと考えら れる $\mathrm{C}_{3} \mathrm{H}_{7}{ }^{+}(m / z=43), \mathrm{C}_{4} \mathrm{H}_{9}{ }^{+}(m / z=57), \mathrm{C}_{7} \mathrm{H}_{7}{ }^{+}(m / z=91)$, $\mathrm{C}_{8} \mathrm{H}_{9}{ }^{+}(m / z=105)$ 等の二次イオンは両方のスペクトルで検 出されている. それに対して $m / z=45,73,147$ 等の二次人 オンは $\mathrm{Ar}_{1550}{ }^{+}$照射での反強く検出された。これらは, PS に由来する炭化水素系フラグメントでは解釈できないピーク であり, フラグメントイオンの出現パターンから PDMS で あると考えられる18). PDMS は $\left(\mathrm{C}_{2} \mathrm{H}_{6} \mathrm{OSi}\right)_{\mathrm{n}}$ を基本構造と する分子であり, Fig. 2 のPS 分析の結果とも整合する. DDB 薄膜試料に関しても同様に, $\mathrm{Ar}_{1550}{ }^{+}$照射でPDMS に 由来する二次イオンピークが $\mathrm{Ar}^{+}$照射よりも明確に検出さ れた. 
Fig. 4 に $\mathrm{PS}$ の $\operatorname{Ar}_{1550}{ }^{+}$照射中の各二次イオン強度の变化 を示す. 照射開始直後の各二次イオン強度を 1 として規格 化した。まず PSの特徵的なフラグメントイオンである $\mathrm{C}_{7} \mathrm{H}_{7}{ }^{+}(m / z=91), \mathrm{C}_{8} \mathrm{H}_{9}{ }^{+}(m / z=105)$ のピーク強度は, ビー 厶照射開始直後にやや上昇するが，その後ゆるやかに減少し 安定した. 一方, PDMS のフラグメントイオンである $\mathrm{C}_{3} \mathrm{H}_{9}$ $\mathrm{Si}^{+}(m / z=73), \mathrm{C}_{5} \mathrm{H}_{15} \mathrm{OSi}_{2}{ }^{+}(m / z=147)$ のピーク強度はビー ム照射開始直後から急激に減少した. PSのフラグメントが ビーム照射開始直後に増加するのは, ビーム照射によるダ メージで表面にPS 分子のフラグメントが発生し一時的に蓄 積したためと考えられる.このため, フラグメントは一時的 に増加するが，さらなるビーム照射によるスパッタで取り除 かれ，その後減少する19). それに対してPDMSのフラグメ ントの急激な減少は, PDMS が表面極近傍に存在し, クラ スターイオンによってスパッタされたことを示唆している.

PDMSの污染源を特定するために, DDB 試料に $\mathrm{Ar}_{1550}{ }^{+}$ ビームを $1.6 \times 10^{13} \mathrm{ions} / \mathrm{cm}^{2}$ 照射した後, 試料を50分間実験 室の大気に開放し, 再度真空中でビームを照射して二次イオ ン強度の変化を調べた。 Fig. 5 にDDB分子イオンと PDMS のフラグメントイオンのピーク強度の変化を示す. DDB 分子イオン強度はビーム照射中にゆっくりと減少して いる.これは, $\mathrm{Ar}_{1550}{ }^{+}$ビーム照射により表面の DDB 分子 層に損傷が蓄積されたことを示唆している. また, DDB 分 子イオン強度は, 試料を大気に開放した前後で変わらなかっ たが, PDMSのフラグメントイオン強度は大幅に増加し た.この結果から本実験で検出されたPDMSの発生源は主 に実験室中の大気であると考えられる。一般に, PDMS は シリコーンとして潤滑油等に幅広く利用されて抢り, 様々な 経路で付着するとされている. プラスチックのケース及び保 存ボックス等だけでなく, 実験室の大気によって污染が発生 したという例も報告されている20).

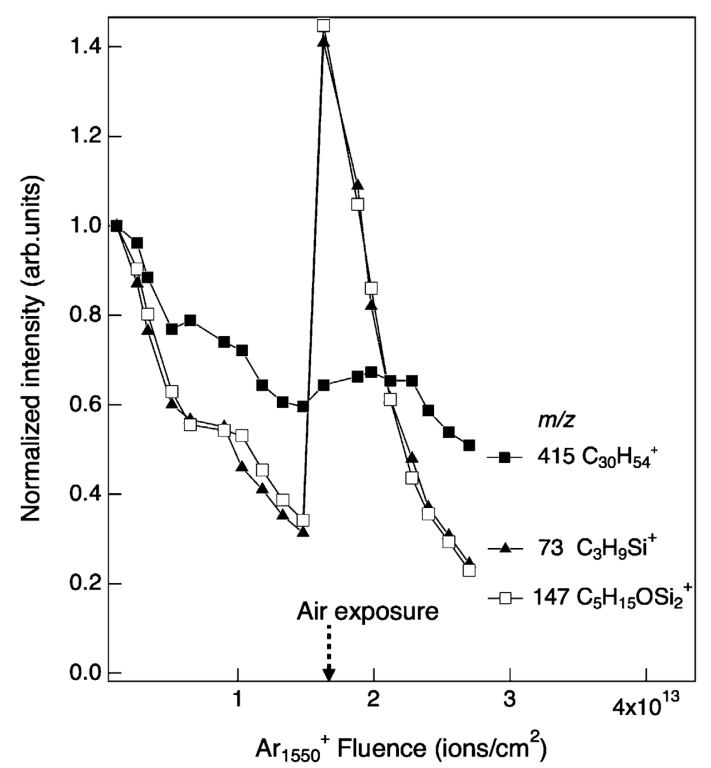

Fig. 5 Relative intensity of DDB molecular ion and PDMS fragment ions during $\mathrm{Ar}_{1550}{ }^{+}$bombardment on DDB thin film sample before and after exposure of the ambient laboratory air.
Table 1 にPS に $\mathrm{Ar}_{1550}{ }^{+}$及び $\mathrm{Ar}^{+}$を照射したときの主な 二次イオンピーク強度の比較を示す. PSのフラグメントイ オンと考えられる炭化水素の二次イオンは Ar クラスターイ オン照射により10-20倍増大されている. 一方, PDMS に由 来する二次イオンはクラスターイオン照射によって70-200 倍増大した．試料のフラグメントイオンがクラスターイオン 照射により10-20倍増大したのは，一つのクラスターイオン が衝突した時に同時に多数の原子が衝突を繰り返すために起 こる効果 (多体衝突効果) によるものと考えている. その他 に重要なのは, $\mathrm{Ar}_{1550}{ }^{+}$イオン照射では, PDMS に由来する 二次イオンが, $\mathrm{Ar}^{+}$イオン照射と比較して70-200倍の高強 度で検出されていることである.ここまで述べてきたような, PDMS に由来する二次イオン強度のみが Ar-GCIB 照射では 著しく増強されるという現象は, DDB 試料においても同様 であった ${ }^{12)}$.

Fig. 6 に PS 試料に $\mathrm{Ar}_{1500}{ }^{+}$及び $\mathrm{Ar}^{+}$を照射したときの O 1s 及び C 1s の光電子強度変化を示す. 光電子取り出し角は

Table 1 Intensity of the major fragment peaks of PS thin film sample with $\mathrm{Ar}_{1550}{ }^{+}$and $\mathrm{Ar}^{+}$bombardments. Data are taken from Ref. 13).

\begin{tabular}{rlrrr}
\hline \hline \multirow{2}{*}{$m / z$} & Assignment & \multicolumn{2}{c}{$\begin{array}{c}\text { Secondary ion yield } \\
\text { (normalized counts) }\end{array}$} & \multirow{2}{*}{$\begin{array}{c}\text { Ratio: } \\
\mathrm{Y}^{+}\left(\mathrm{Ar}_{1550^{+}}\right)\end{array}$} \\
\cline { 3 - 4 } & & $\mathrm{Y}^{+}{ }_{\left(\mathrm{Ar}_{1550^{+}}\right)}$ & $\mathrm{Y}^{+}\left(\mathrm{Ar}^{+}\right)$ & \\
\hline 43 & $\mathrm{C}_{3} \mathrm{H}_{7}{ }^{+}, \mathrm{CH}_{3} \mathrm{Si}^{+}$ & 176 & 10 & 18 \\
45 & $\mathrm{CH}_{5} \mathrm{Si}^{+}$ & 200 & 1 & 200 \\
73 & $\mathrm{C}_{3} \mathrm{H}_{9} \mathrm{Si}^{+}$ & 2304 & 15 & 154 \\
91 & $\mathrm{C}_{7} \mathrm{H}_{7}{ }^{+}$ & 2448 & 138 & 18 \\
105 & $\mathrm{C}_{8} \mathrm{H}_{9}{ }^{+}$ & 526 & 27 & 20 \\
147 & $\mathrm{C}_{5} \mathrm{H}_{15} \mathrm{Si}_{2} \mathrm{O}^{+}$ & 294 & 4 & 74 \\
\hline
\end{tabular}

(a)

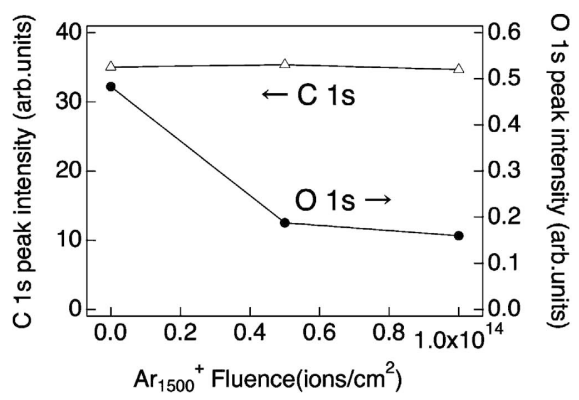

(b)

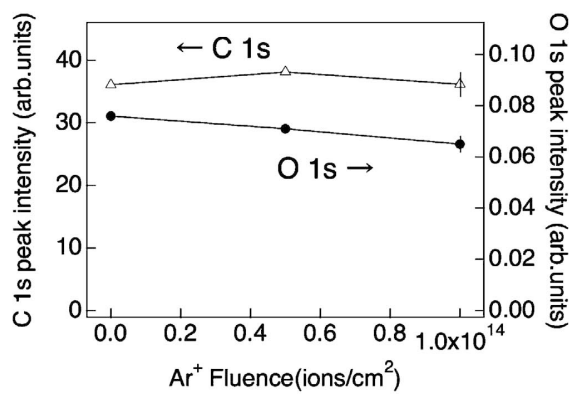

Fig. 6 Irradiated ion fluence dependence of the $O$ 1s and $C$ 1s peak intensity of the DDB sample during (a) Ar GCIB and (b) $\mathrm{Ar}^{+}$irradiation, respectively. The electron take-off angle was $60^{\circ}$ to the surface plane. 


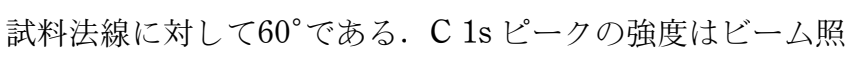
射中にほとんど変化しないが，O 1s ピーク強度はスパッタ により減少する．特に $\operatorname{Ar}_{1500}{ }^{+}$照射で著しく減少し， $5 \times$ $10^{13} \mathrm{ions} / \mathrm{cm}^{2}$ 照射する間に約 $60 \%$ 減少した。一方, $\mathrm{Ar}^{+}$照 射では約 $6 \%$ しか減少しなかった.

Arクラスターイオン照射で表面の PDMS を極めて敏感に 検出するメカニズムを検討する. ある化学種 $\mathrm{m}$ の二次イオ ン収率 $\left(Y_{\mathrm{m}}^{+}\right)$は, $Y_{\mathrm{m}}$ をスパッタ率, $\eta_{\mathrm{m}}{ }^{+}$をイオン化率, $\theta_{\mathrm{m}}$ は化学種 $\mathrm{m}$ の濃度とすると,

$$
Y_{\mathrm{m}}^{+}=Y_{\mathrm{m}} \cdot \eta_{\mathrm{m}}{ }^{+} \cdot \theta_{\mathrm{m}}
$$

で表される，また，スパッタ率は，Fを 1 次イオン照射量と して

$$
Y_{\mathrm{m}}=\mathrm{d} \theta_{\mathrm{m}} / \mathrm{d} F
$$

と表せるから, Fig. 6 の 0 1s ピーク強度変化の初期の傾き から，PDMSのスパッタ率を大まかに見積もることができ る.その結果, $\operatorname{Ar}_{1500}{ }^{+}$照射によるPDMSのスパッタ率 $Y_{\mathrm{PDMS}}$ は $\mathrm{Ar}^{+}$照射と比較して少なくとも約60倍以上高かっ た. 同様の解析をDDB 薄膜試料についても行ったところ, $\mathrm{Ar}_{1500}{ }^{+}$による $Y_{\mathrm{PDMS}}$ は80倍以上高かった ${ }^{12)}$.

ここでイオン化率についても検討する. Fig. 3 のスペクト ルは Static SIMS 条件下で測定しているため, 式(1)におい て PDMSの濃度 $\theta_{\mathrm{m}}$ は $\mathrm{Ar}_{1550}{ }^{+}$照射の場合と $\mathrm{Ar}^{+}$照射の場 合で等しいと考えてよい。 そのため, Table 1 の $Y_{\mathrm{m}}{ }^{+}$ $\left(\mathrm{Ar}_{1550}{ }^{+}\right) / Y_{\mathrm{m}}{ }^{+}\left(\mathrm{Ar}^{+}\right)$の值と Fig. 3 から見積もったスパッタ 率から, ArクラスターイオンとAr単原子イオンを照射し た場合のイオン化率を，相対的に見積もることができる．例 として, $\mathrm{C}_{5} \mathrm{H}_{15} \mathrm{OSi}_{2}{ }^{+}$の場合を考えてみると, $\eta_{\mathrm{C}_{5} \mathrm{H}_{15} \mathrm{OSi}_{2}{ }^{+}}$ $\left(\mathrm{Ar}_{1550}{ }^{+}\right) / \eta_{\mathrm{C}_{5} \mathrm{H}_{15} \mathrm{OSi}_{2}{ }^{+}}\left(\mathrm{Ar}^{+}\right)$は，たかだか 1.2 程度である.すな わち, PDMS 由来のフラグメントイオン強度が $\mathrm{Ar}_{1550}{ }^{+}$照射 では $\mathrm{Ar}^{+}$を照射した場合よりも約 $70 〜 200$ 倍高いのは, $\mathrm{Ar}_{1550}{ }^{+}$を照射した場合は, PDMS が存在する試料の極浅い 領域を, $\mathrm{Ar}^{+}$照射よりも効率的にスパッタしているためで あると考えられる.

\section{2 無機材料表面の分析}

Fig. 7 に, ITO ガラス試料に $5 \mathrm{kV}$ で $\mathrm{Ar}_{1550}{ }^{+}$を照射した
際の SIMS スペクトル (a) と, $\mathrm{Ar}^{+}$を照射した際の SIMS ス ペクトル (b)を示す. $\mathrm{Ar}^{+}$照射では ITO ガラスの特徵的な 2 次イオンである $\operatorname{In}^{+}(m / z=115)$ が極めて強く検出されたが, $\mathrm{Ar}_{1550}{ }^{+}$照射では, $\mathrm{In}^{+}$のピークが小さい一方で, 上記の有 機物試料と同様に $m / z=45,73,147$ RDMS に由来する二 次イオンが強く検出された.

Table 2 に ITO ガラス試料に $\mathrm{Ar}_{1550}{ }^{+}$及び $\mathrm{Ar}^{+}$を照射し たときの主な二次イオンピーク強度の比較を示す．この場合 も，3.1で述べた有機高分子試料と同様に PDMS が $\mathrm{Ar}^{+}$照 射よりも強く検出されている. 一方, $\mathrm{In}^{+}$ピークの強度は著 しく小さくなっている。これは, GCIBのスパッタ収率が, 無機物に関しては極端に低いためであると考えられる21). このため ArクラスターSIMS は有機, 無機を問わず試料表 面に存在する微量有機分子の高感度分析には有利であるが, 無機材料自体の分析には不向きであると考えられる.

\section{4. よ め}

本研究では, サイズ選別型 Ar ガスクラスターSIMS 装置 を有機物（PS, DDB）薄膜試料及び無機物（ITO ガラス） 試料に適用した。その結果，ArガスクラスターSIMS では 有機高分子試料の表面に存在する微量污染物質を, Ar 単原 子イオンを一次イオンとした場合と比較して，70-200倍以 上強く検出した． Ar-GCIB 及び $\mathrm{Ar}^{+}$イオンビーム照射によ り試料表面から放出される二次イオンを SIMSにより，ま た試料表面がスパッタされる様子をXPSにより分析した結 果, $\mathrm{Ar}$ クラスターイオンは有機高分子材料表面の極浅い領

Table 2 Intensity of the major secondary ion peaks of ITO glass sample with $\mathrm{Ar}_{1550}{ }^{+}$and $\mathrm{Ar}^{+}$bombardments. Data are

\begin{tabular}{|c|c|c|c|c|}
\hline \multirow[t]{2}{*}{$m / z$} & \multirow{2}{*}{ Assignment } & \multicolumn{2}{|c|}{$\begin{array}{l}\text { Secondary ion yield } \\
\text { (normalized counts) }\end{array}$} & \multirow{2}{*}{$\begin{array}{c}\text { Ratio: } \\
\mathrm{Y}^{+}\left(\operatorname{Ar}_{\left.1550^{+}\right)}\right) \\
\mathrm{Y}^{+}\left(\mathrm{Ar}^{+}\right)\end{array}$} \\
\hline & & $\mathrm{Y}^{+}\left(\operatorname{Ar}_{1550}{ }^{+}\right)$ & $\mathrm{Y}^{+}\left(\mathrm{Ar}^{+}\right)$ & \\
\hline 45 & $\mathrm{CH}_{5} \mathrm{Si}^{+}$ & 338 & 42 & 8 \\
\hline 73 & $\mathrm{C}_{3} \mathrm{H}_{9} \mathrm{Si}^{+}$ & 829 & 74 & 11 \\
\hline 115 & $\mathrm{In}^{+}$ & 237 & 2922 & 0.08 \\
\hline 147 & $\mathrm{C}_{5} \mathrm{H}_{15} \mathrm{OSi}_{2}{ }^{+}$ & 85 & 15 & 5.7 \\
\hline
\end{tabular}
taken from Ref. 13).

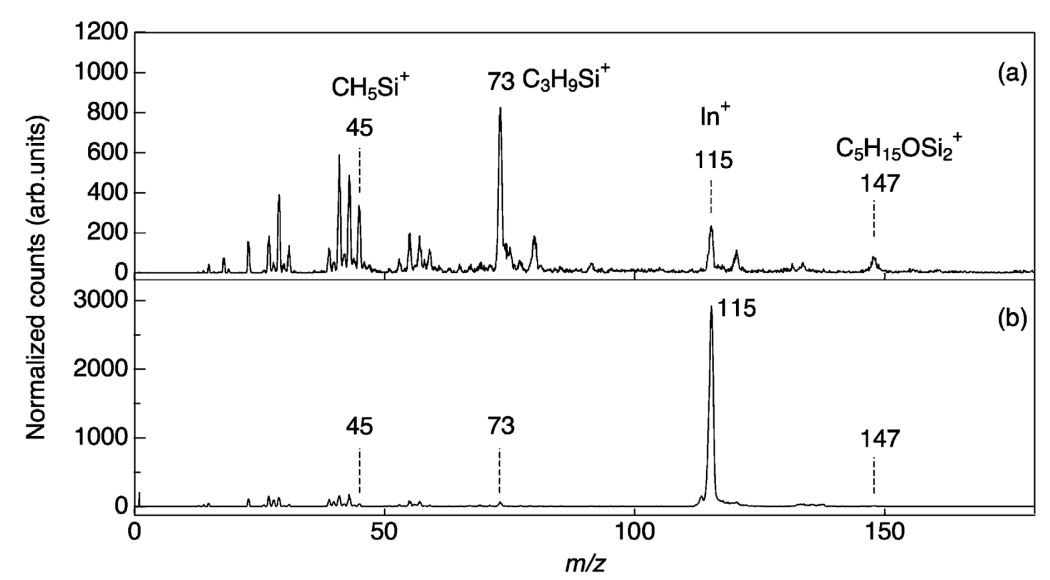

Fig. 7 Secondary ion mass spectra of ITO glass sample for (a) $\mathrm{Ar}_{1550}{ }^{+}$and (b) $\mathrm{Ar}^{+}$SIMS at an acceleration voltage of $5 \mathrm{kV}$. 
域を, $\mathrm{Ar}$ 単原子イオンの少なくとも数十倍以上効率的にス パッタし, その結果, 表面の污染物質を従来型 SIMSより も敏感に検出していることがわかった. 本手法は化学工業, エレクトロニクス, 材料開発など有機高分子材料開発の分野 で極めて有用であると考えられる.

\section{5. 謝 辞}

本研究の一部は科学技術振興事業団 (JST) の先端計測分 析技術・機器開発事業の委託を受けて行われました. また， 本研究の一部は科学研究費補助金（若手研究 B, 23760037) の助成を受けております。

\section{[文献 $]$}

1) N. Toyoda, J. Matsuo, T. Aoki, I. Yamada and D. B. Fenner: Nucl. Instrum. Methods B, 190 (2002) 860.

2) S. Ninomiya, Y. Nakata, Y. Honda, K. Ichiki, T. Seki, T. Aoki and J. Matsuo: Appl. Surf. Sci., 255 (2008) 1588.

3) K. Mochiji, M. Hahinokuchi, K. Moritani and N. Toyoda: Rapid Commun. Mass Spectrom., 23 (2009) 648.

4) S. Ninomiya, K. Ichiki, H. Yamada, Y. Nakata, T. Seki, T. Aoki and J. Matsuo: Rapid Commun. Mass Spectrom., 23 (2009) 1601.

5) J. L. S. Lee, S. Ninomiya, J. Matsuo, I. S. Gilmore, M. P. Seah and A. G. Shard: Anal. Chem., 82 (2010) 98.

6) D. C. Jacobs: Annu. Rev. Phys. Chem., 53 (2002) 379.

7) K. Moritani, S. Houzumi, K. Takeshima, N. Toyoda and K.
Mochiji: J. Phys. Chem. C, 112 (2008) 11357.

8) K. Moritani, M. Hashinokuchi, J. Nakagawa, T. Kashiwagi, N. Toyoda and K. Mochiji: Appl. Surf. Sci., 255 (2008) 948.

9) K. Mochiji: J. Anal. Bioanal. Tech., S2 (2011) 001.

10) K. Moritani, G. Mukai, M. Hashinokuchi and K. Mochiji: Appl. Phys. Express, 2 (2009) 046001.

11) K. Moritani, G. Mukai, M. Hashinokuchi and K. Mochiji: Surf. Interface Anal., 43 (2011) 241.

12) M. Tanaka, K. Moritani, T. Hirota, N. Toyoda, I. Yamada, N. Inui and K. Mochiji: Rapid Commun. Mass Spectrom., 24 (2010) 1405.

13) K. Moritani, M. Tanaka, N. Inui and K. Mochiji: Surf. Interface Anal., 45 (2013) 143.

14) K. Moritani, M. Hashinokuchi, J. Nakagawa, T. Kashiwagi, N. Toyoda and K. Mochiji: Appl. Surf. Sci., 255 (2008) 948.

15) K. Moritani, M. Hashinokuchi, G. Mukai and K. Mochiji: IEEJ Transactions on Electronics, Information and Systems, 129 (2009) 288 [in Japanese].

16) N. Toyoda, Y. Maeshima and I. Yamada: Nucl. Instrum. Meth. B, 257 (2007) 662.

17) P. R. Vlasak, D. J. Beussman, M. R. Davenport and C. G. Enke: Rev. Sci. Instrum., 67 (1996) 68.

18) J. G. Newmann, B. A. Carlson, R. S. Michael, J. F. Moulder and T. A. Hohlt: Static SIMS Handbook of Polymer Analysis (Perkin-Elmer, Minnesota, USA, 1991) p. 164.

19) I. S. Gilmore and M. P. Seah: Surf. Interface Anal., 24 (1996) 746.

20) G. J. Leggett, J. C. Vickerman, D. Briggs and N. J. Hearn: J. Chem. Soc., Faraday Trans., 88 (1992) 297.

21) M. P. Seah: J. Phys. Chem. C, 117 (2010) 12622. 